NOTA

\title{
NEW RECORDS OF COMMON DOLPHINS (CETACEA: DELPHINIDAE) IN DEEP WATERS OF THE SOUTHWESTERN ATLANTIC OCEAN
}

\author{
Eduardo Juri ${ }^{1,2}$ \\ 1 Dirección de Coordinación Científica y Gestión Ambiental, Instituto Antártico Uruguayo - 8 de Octubre, CP \\ 11600, Montevideo, Uruguay. \\ 2 Laboratorio de Mamíferos Marinos, Museo Nacional de Historia Natural - 25 de mayo 582 CP.11.000 \\ Montevideo, Uruguay.
}

Autor para correspondencia: edujuri@gmail.com

\begin{abstract}
Common dolphins (genus Delphinus) constitute one of the most widely distributed small cetaceans commonly found world-wide in temperate, tropical and subtropical seas. In the Southwestern Atlantic Ocean region, they are distributed from the north of Brazil to central Argentina in waters from $18 \mathrm{~m}$ to $1435 \mathrm{~m}$ of depth. This paper presents three new records of common dolphins in Uruguayan deep waters $(>2800 \mathrm{~m})$. These records represent the maximum depths known for the genus Delphinus in the Southwestern Atlantic Ocean and constitute an extension of its longitudinal distribution range.
\end{abstract}

Keywords: Delphinus, distribution, longitudinal range, sightings.

\section{RESUMEN}

Nuevos registros de delfines comunes (Cetacea: Delphinidae) en aguas profundas del Océano Atlático Suroeste. Los delfines comunes (género Delphinus) son uno de los pequeños cetáceos mayormente distribuidos en los mares tropicales y templados del mundo. En la región del Océano Atlántico Sudoccidental se distribuyen desde el norte de Brasil hasta el centro de Argentina en aguas de $18 \mathrm{~m}$ a $1435 \mathrm{~m}$ de profundidad. Este trabajo presenta tres nuevos registros de delfines comunes en aguas profundas uruguayas $(>2800 \mathrm{~m})$. Estos registros representan las máximas profundidades que se conocen para el género Delphinus en el Océano Atlántico Sudoccidental y constituyen una extensión de su rango de distribución longitudinal.

Palabras clave: avistamientos, Delphinus, distribución, rango longitudinal.

Common dolphins (genus Delphinus) represent one of the most widely distributed small cetaceans as they are found world-wide in temperate, tropical and subtropical seas (Evans, 1994). In the Southwestern Atlantic Ocean, the most recent review conducted on the biogeography of the genus Delphinus identified three stocks of common dolphins (Tavares et al., 2010): one located in the north of Brazil (Pará State, stock 1) another located in the southeastern of Brazil (from Rio de Janeiro State to Santa Catalina State, stock 2), and the third one located from the south of Brazil (Santa Catalina State) to the central area of Argentina (Chubut Province, Stock 3). In southeastern Brazil sightings were restricted to coastal waters in depths ranging from $18 \mathrm{~m}$ to $70 \mathrm{~m}$. For the area that extends from southern Brazil to Argentina sightings were recorded in deeper waters, ranging from $71 \mathrm{~m}$ to $1435 \mathrm{~m}$ in the middle continental shelf and slope, with occasional coastal sightings in Argentina (Tavares et al., 2010). In Uruguayan waters, information about cetacean distribution comes primarily from stranding records (as reported by Del Bene et al., 2006; González \& Martínez, 2010), as well as a small number of offshore sighting records (Tavares et al., 2010; Juri et al., 2012; Passadore et al., 2015). The aim of this paper is to present new records of common dolphins for deeper waters (> $2800 \mathrm{~m}$ ) in the Southwestern Atlantic Ocean.

The study area is located in the Southwestern Atlantic Ocean, between latitude $34 \square$ and $38 \square$ S, an area that overlaps with the Subtropical Convergence. The Subtropical Convergence is the most relevant oceanographic feature of the Southwestern Atlantic Ocean; which is the encounter of cold waters from the Malvinas/Falkland current with warm waters from the subtropical Brazil current (Seeliger et al., 1997). The Subtropical Convergence is considered one of the most productive regions in all the oceans, which offers great amount of food supplies and/or reproductive habitat for nektonic species such as fishes, squids and marine mammals (Acha et al., 2004).

Data were recorded by the author during marine mammal mitigation programs on seismic surveys in the Southwestern Atlantic Ocean, from November 2012 to April 2013, and from October 2013 to January 2014 in depths ranging from $1300 \mathrm{~m}$ to $4100 \mathrm{~m}$. Geographical position and bathymetric data were obtained from the navigation instruments of the vessel. In this study, the only sightings considered where those in which the identification of the species was absolutely unquestionable, supported by photographic record.

During the sampling effort ( 9 hours a day on 
Table 1. Records of common dolphins beyond the continental shelf ( $>200 \mathrm{~m}$ depth) in Uruguayan waters.

\begin{tabular}{|c|c|c|c|c|c|}
\hline Date & Latitude & Longitude & Depth (m) & Number of individuals & Source \\
\hline 7 March 2002 & $35^{\circ} 22.200^{\prime} \mathrm{S}$ & $52^{\circ} 43.800^{\prime} \mathrm{W}$ & 219 & 1 bycatch & Passadore et al. (2015) \\
\hline 6 September 2002 & $34^{\circ} 46.0002 S$ & $52^{\circ} 03.0002 \mathrm{~W}$ & 342 & 2 bycatch & Juri et al. (2012) \\
\hline 25 October 2002 & $35^{\circ} 49.2002 S$ & $52^{\circ} 13.200^{\prime} \mathrm{W}$ & 819 & 2 bycatch & Passadore et al. (2015) \\
\hline 14 November 2003 & $35^{\circ} 02.0002 S$ & $51^{\circ} 13.0002 \mathrm{~W}$ & 1435 & NA & Tavares et al. (2010) \\
\hline 15 December 2005 & $35^{\circ} 01.020^{\prime} \mathrm{S}$ & $52^{\circ} 15.000^{\prime} \mathrm{W}$ & 957 & 1 bycatch & Passadore et al. (2015) \\
\hline 17 December 2005 & $35^{\circ} 03.000^{\prime} \mathrm{S}$ & $52^{\circ} 33.000^{\prime} \mathrm{W}$ & 520 & 1 bycatch & Passadore et al. (2015) \\
\hline 13 December 2012 & $36^{\circ} 15.709^{\prime} \mathrm{S}$ & $52^{\circ} 12.999^{\prime} \mathrm{W}$ & 2807 & $H \cdot 50$ & Present study \\
\hline 5 November 2013 & $37^{\circ} 49.094^{\prime} \mathrm{S}$ & $52^{\circ} 15.165^{\prime} \mathrm{W}$ & 4070 & $H \cdot 100$ & Present study \\
\hline 31 November 2013 & $36^{\circ} 19.050^{\prime} \mathrm{S}$ & $51^{\circ} 27.560^{\prime} \mathrm{W}$ & 3552 & $\mathrm{H} \cdot 40$ & Present study \\
\hline
\end{tabular}

NA: not available

average), a total of three sighting events were recorded. On December 13th, 2012, a group of approximately 50 individuals was observed in waters over $2807 \mathrm{~m}$ deep. On November 5th, 2013, a group of approximately 100 individuals was sighted over 4070m deep. Finally, on November 31st, 2013, a sighting of approximately 40 individuals was recorded at a depth of 3552 m (Table
1). The groups of common dolphins can be composed of hundreds or thousands of individuals (Perrin, 2009). In the Southwestern Atlantic Ocean groups of up to 30 individuals are more frequently observed, however groups of 50 to 100 are commonly sighted (Tavares et al., 2010). Therefore, the sightings presented here match with the group size reported for the region.

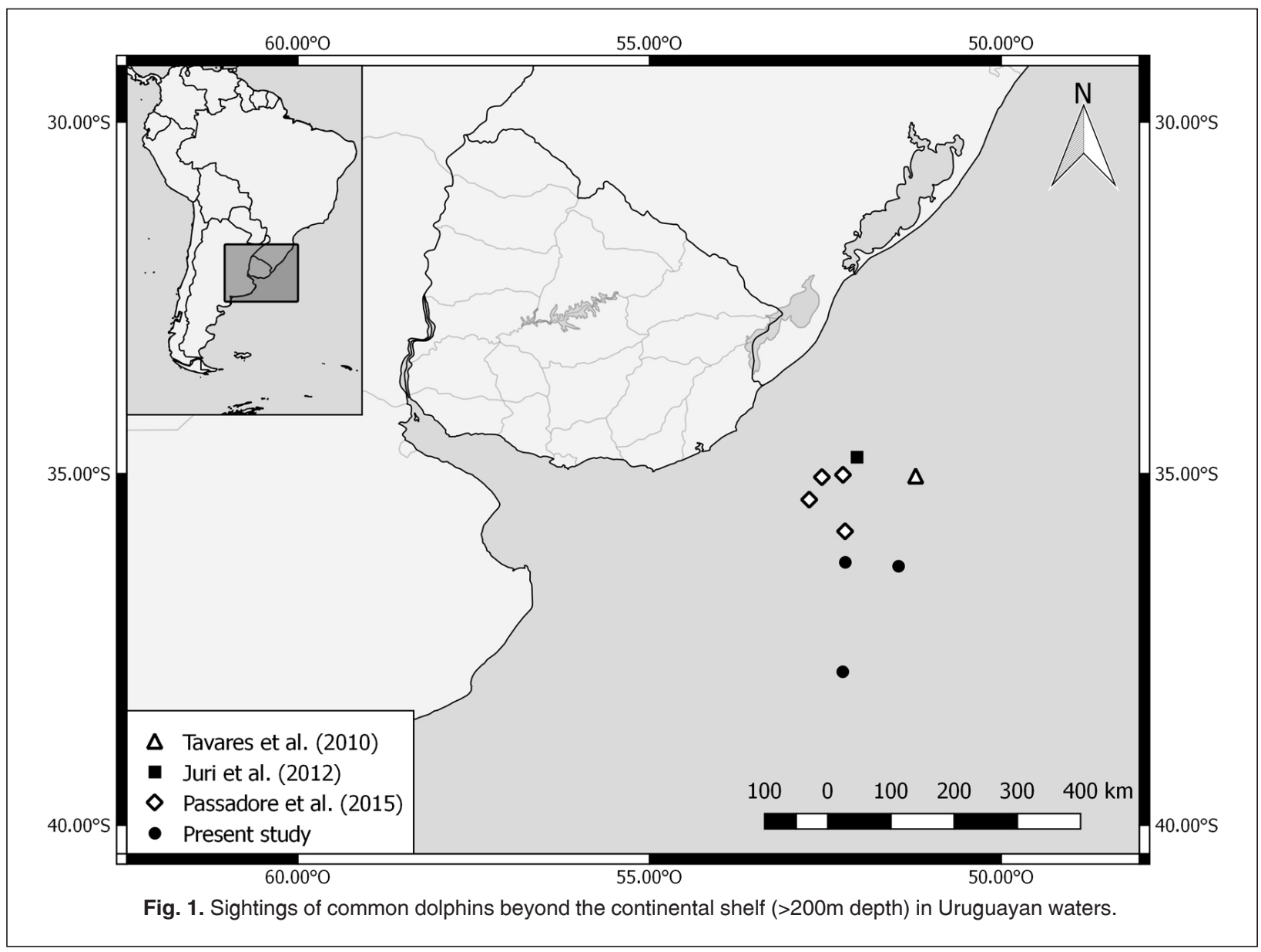

Bol. Soc. Zool. Uruguay (2ª época). 2018. Vol. 27 (2): 60-62 ISSN: 0255-4402 
Previous records for the study area (Fig.1) corresponded to: one specimen captured over $342 \mathrm{~m}$ depth (Juri et al., 2012), four specimens captured incidentally by fishing vessels over $219 \mathrm{~m}, 520 \mathrm{~m}, 819 \mathrm{~m}$ and 957m depth (Passadore et al., 2015), and a sighting in the marine boundary between Brazilian and Uruguayan waters over $1435 \mathrm{~m}$ deep (Tavares et al., 2010).

In the Southwestern Atlantic Ocean the records of common dolphins in Brazilian deepest waters occurred in Rio Grande do Sul state at depths of $1435 \mathrm{~m}, 1190 \mathrm{~m}$ and 1000m (Tavares et al., 2010). In Argentine waters there are incidental captures of common dolphins over the outer continental shelf off Patagonia in depths between 30m and 100m (Crespo et al., 2000) and near Mar del Plata the author observed common dolphins over depths of $95 \mathrm{~m}$ and $80 \mathrm{~m}$ in different occasions. Therefore, the records presented here represent the maximum depths known for the genus Delphinus in the Southwestern Atlantic Ocean and constitute an extension of the longitudinal distribution range, as also show the need to carry out surveys in areas where there is little information, as being beyond the continental shelf.

\section{ACKNOWLEDGMENTS}

I am grateful to Maurício Tavares and Alfredo Le Bas for their permanent support and their valuable comments that helped to improve this work.

\section{REFERENCES}

Acha E.M., Mianzan H.W., Guerrero R.A., Favero M. \& Bava J. 2004. Marine fronts at the continental shelves of austral South America physical and ecological processes. Journal of Marine Systems, 44: 83-105.

Crespo E.A., Alonso M.K., Dans S.L., García N.A., Pedraza S.N., Coscarella M., González R. 2000. Incidental catch of dolphins in mid-water trawls for Argentine anchovy (Engraulis anchoita) off the Argentine shelf. Journal of Cetacean
Research and Management, 2: 11-16.

Del Bene D., Little V., Rossi R. \& Le Bas, A. 2006. Revisión preliminar de registros de varamientos de cetáceos en la costa uruguaya de 1934 a 2005. En: R. Menafra, L. Rodríguez-Gallego, F. Scarabino \& D. Conde (Eds.) Bases para la conservación y manejo de la zona costera uruguaya, pp. 297-303. Vida Silvestre Uruguay, Montevideo.

Evans W.E. 1994. Common dolphin, White-bellied porpoise Delphinus delphis Linnaeus 1758. En: S.H. Ridgeway \& R.J. Harrison (Eds) Handbook of Marine Mammals, Volume 5: The First Book of Dolphins, pp. 191-224. Academic Press, London.

González E.M. \& Martínez J.A. 2010. Mamíferos de Uruguay. Guía de Campo e introducción a su estudio y conservación. $1^{\underline{a}}$ edición. Banda Oriental, Montevideo. 464 pp.

Juri E., Valdivia M. \& Le Bas A. 2012. Presence of Delphinus capensis and Delphinus delphis (Cetacea: Delphinidae) in Uruguay. Marine Biodiversity Records, 5 (e3): 1-4.

Passadore C., Domingo A. \& Secchi E.R. 2015. Analysis of marine mammal bycatch in the Uruguayan pelagic longline fishery operating in the Southwestern Atlantic Ocean. ICES Journal of Marine Science, 72(5): 1637-1652.

Perrin W.F. 2009. Common Dolphins Delphinus delphis and D. capensis. En: W. F. Perrin, B. Würsig \& J.G.M. Thewissen (Eds) Encyclopedia of Marine Mammals (Second Edition), pp. 255-259. Academic Press, San Diego.

Seeliger U., Odebrecht C. \& Castello J.P. 1997. Subtropical convergence environments-the coast and sea in the south-western Atlantic, Springer-Verlag, Berlin. 207 pp.

Tavares M., Moreno I.B., Siciliano S., Rodríguez D., Santos M.C. de O. \& Fabián M.E. 2010. Biogeography of common dolphins (genus Delphinus) in the Southwestern Atlantic Ocean. Mammal Review, 40: 40-64.

Fecha de Recibido: 13 de agosto de 2018 Fecha de Aceptado: 2 de octubre de 2018 